\title{
Update and Review of the Treatment of Erythema Elevatum Diutinum
}

\author{
Mohammed Al Abadie ${ }^{1 *}$, Faris Oumeish ${ }^{1}$, Mohammed Al-Rubaye ${ }^{1}$ and Anjam Tariq ${ }^{2}$ \\ ${ }^{1}$ Department of Dermatology, The Royal Wolverhampton NHS Trust, United Kingdom \\ ${ }^{2}$ Department of Genitourinary Medicine, The Royal Wolverhampton NHS Trust, United Kingdom
}

*Corresponding author: Mohammed Al Abadie, PhD, FRCP Consultant \& Director of Dermatology, Royal Wolverhampton NHS

Trust. Wolverhampton, UK

\begin{tabular}{|c|c|}
\hline ARTICLE INFO & ABSTRACT \\
\hline Received: 慧 October 03, 2019 & \multirow{3}{*}{$\begin{array}{l}\text { It presents as brown to red-purplish nodules, papules and plaques on the extensor } \\
\text { surface of the extremities. It may present with features of leukocytoclastic vasculitis at } \\
\text { the early stage, while at later stage it shows fibrosis and granulation tissue. Dapsone is } \\
\text { currently the most effective treatment. Other therapies include surgical excision, meth- } \\
\text { otrexate, colchicine, antibiotics and steroids. This paper will present a review of treat- } \\
\text { ment of EED along with our experience in treating an HIV positive patient with EED. }\end{array}$} \\
\hline 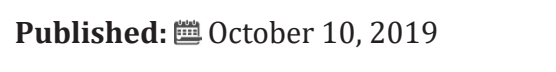 & \\
\hline $\begin{array}{l}\text { tation: Al Abadie M, Ou } \\
\text { ubaye M, Tariq A. Update }\end{array}$ & \\
\hline
\end{tabular}

of the Treatment of Erythema Elevatum Diutinum. Biomed J Sci \& Tech Res 21(5)2019. BJSTR. MS.ID.003662.

\section{Introduction}

Erythema elevatum diutinum (EED) is a rare chronic leukocytoclastic vasculitis dermatosis of unknown aetiology that was described by Hutchinson in 1888 and in 1894 was named by Radcliffe-Crocker and Williams .It presents as brown to red-purplish nodules, papules and plaques on the extensor surface of the extremities [1]. It tends to present earlier in patients diagnosed with HIV and most commonly presents between the 4th to 6th decade although it can present at any age and has no racial predilection [2]. The most common associated symptom is arthralgia [2]. Skin biopsy is important to make a diagnosis of (EED).Dapsone is currently the most effective treatment [2]. Other therapies include surgical excision, methotrexate, colchicine, antibiotics and steroids.

\section{Treatment}

In a review of 66 cases of EED treated with dapsone monotherapy lead to complete resolution in $80 \%$ of the cases [2]. A Agusti-Mejias et al reported a 68 year female patient that presented with vesiculobullous lesions mimicking a vesiculobullous disease on the basis of clinical appearance and histology a diagnosis of EED was made and the patient was treated with dapsone, $100 \mathrm{mg} / \mathrm{d}$ and hydroxychloroquine $200 \mathrm{mg} / \mathrm{d}$ with great clinical improvement over 4-5 weeks
[3]. P smith et al reported a 35 female patient that presented with multiple painful progressively increasing raised blistering lesions on the dorsa of the feet for 8 months and 2 firm non tender nodules on her left elbow after a skin biopsy was taken that confirmed EED the patient was treated with dapsone $100 \mathrm{mg} / \mathrm{d}$ in combination with clobetasol propionate and fusidic acid cream twice daily to be applied to the lesions which helped flatten the lesion [4].

K Farsinejad et al reported a 77-year-old woman who developed EED that had an atypical presentation on the palms, soles, back of the hands and feet. She presented with 2-year history of reddishbrown nodules and plaques on the back of fingers and verrucous plaques on the palms and soles, reminiscent of confluent warty lesions. Histopathological findings and the fact that the patient had raised level of IgA confirmed the diagnosis of EED with IgA gammopathy. The patient was treated with dapsone $50 \mathrm{mg} / \mathrm{d}$ after 5 months of treatment the lesions decreased in size and number and after 1 year of treatment lesions on the palms and soles cleared and the plaques on the back of the fingers and toes were by far smaller [5]. E Soubeiran et al reported a 77-year old man with a 6 month history of nodules on the extensor surfaces of the fingers 
and elbows and later on developed erythematous nodules on the right thigh. Histology and clinical findings confirmed the diagnosis of EED. Treatment with steroids was initiated but there was no improvement, later on dapsone therapy at high doses failed to bring any improvement so therapy was discontinued after 6 months so the last resort was to excise some of the nodules and use a splitskin graft.

The lack of response to treatment with dapsone and steroids could be explained by the advanced stage of the disease and significant fibrosis in the nodules [6]. In our experience we treated an HIV positive patient who had a biopsy proven Erythema Elevatum diutinum initially with Dapsone $50 \mathrm{mg}$ od which lead to some improvement for 2 weeks but not change after. The dose was increased to $100 \mathrm{mg}$ od after two months for next nine months. The lesions were gradually getting smaller with up to $50 \%$ improvement. Upon increasing the dose of Dapsone to 100/150 mg on alternate days it had a significant impact with $75 \%$ improvement (Figure 1), despite the fact that in HIV there is advanced fibrosis and most cases might not respond to dapsone. EED with oral ulceration was treated with a combination of colchicine 500 micrograms 3 times daily, dapsone $50 \mathrm{mg}$ on alternate days and mycofenolate mofetil 1.5 g [7]. C Mahabir et al reported a 60-year-old African American with a 5 year history of multiple growing nodules on the elbow and metacarpophalangeal joints. He was unresponsive to multiple intralesional steroid injections, later on histopathology confirmed EED unfortunately due to the patient having a low level of G6PD and sulfa allergy he was not a candidate for dapsone, so the patient underwent multiple surgical excisions and healed with complications [8].

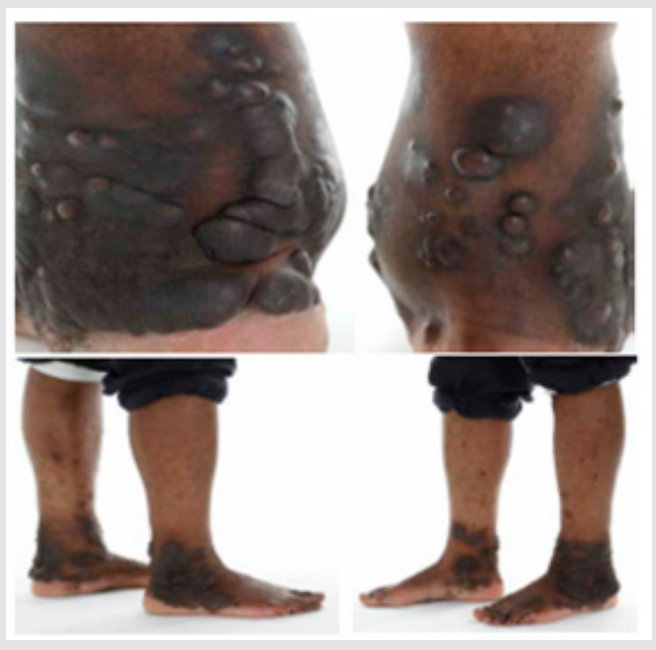

Figure 1.

G Raghurama Rao reported a 52 year old HIV positive female on ART (Zidovudine +Lamivudine+ Nevirapine) for seven years who developed multiple dusky red nodules and plaques over the feet, ankles ,soles, shins, knees, and elbows. Two biopsies were done, and histopathology confirmed EED. The patient initially was treated with dapsone $100 \mathrm{mg} /$ day, and after the first 2 weeks the majority of the lesions resolved. But dapsone had to be stopped because the patient developed a hypersensitivity reaction to dapsone. So, after 4 weeks Colchicine $0.5 \mathrm{mg}$ twice daily was administered instead of dapsone. The response to colchicine was slow with regression being noted in smaller lesions, while larger lesions were still in the process of regression [9].

\section{Histology Review}

Histologically EED could present variably depending on the evolutionary stage of the disease. It may present with features of leukocytoclastic vasculitis at the early stage (Figure 2) while at later stage it shows fibrosis and granulation tissue.

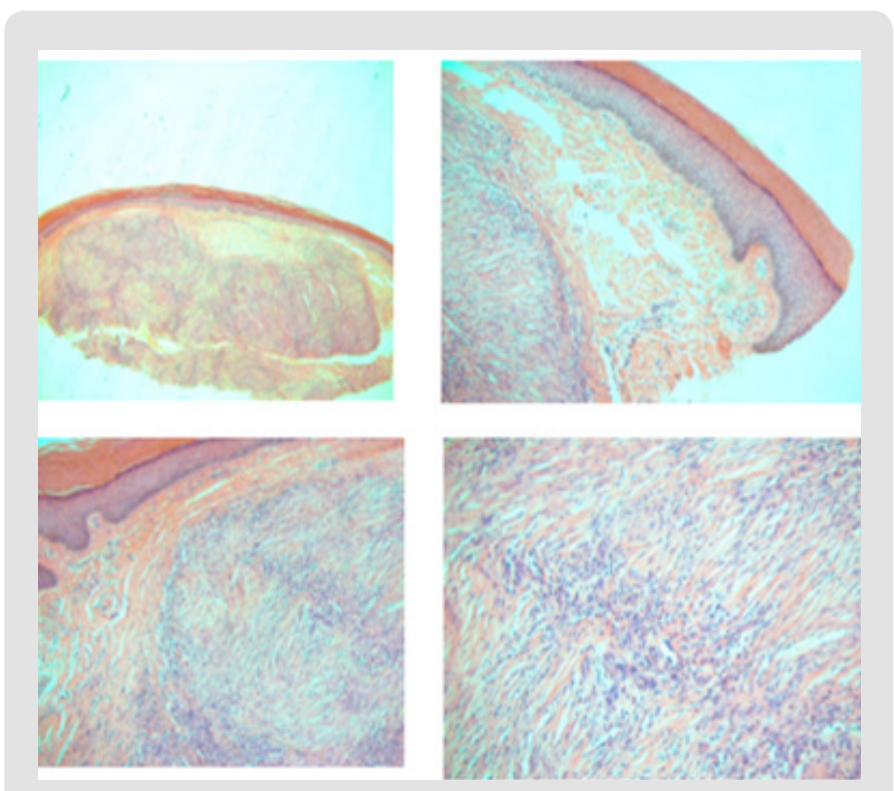

Figure 2.

\section{Conclusion}

EED is a rare skin condition, were treatment found to be challenging. A review of all treatment given showed Dapsone to be more effective than other treatment options. The higher dose of Dapsone seems to have an impact on response. A possible combination of treatment in the future might give even better response, again the earlier the patient is treated seems to respond better.

\section{References}

1. Grabbe J, Haas N, Möller A, Henz BM (2000) Erythema elevatum diutinum--evidence for disease-dependent leucocyte alterations and response to dapsone. Br J Dermatol 143(2): 415-420.

2. Momen SE, Jorizzo J, Al Niaimi F (2014) Erythema elevatum diutinum: a review of presentation and treatment. J Eur Acad Dermatol Venereol 28(12): 1594-1602.

3. Agusti Mejias A, Messeguer Badia F, Rodriguez M, Pérez A, Alegre V (2011) Erythema elevatum diutinum mimicking a vesiculobullous disease. Int J Dermatol 50(9): 1126-1128. 
4. Smitha P, Sathish P, Mohan K, Sripathi H, Sachi G (2011) A case of extensive erosive and bullous erythema elevatum diutinum in a patient diagnosed with human immunodeficiency virus (HIV). Int J Dermatol 50(8): 989-991

5. Barzegar M, Davatchi CC, Akhyani M, Nikoo A, Daneshpazhooh M (2009) An atypical presentation of erythema elevatum diutinum involving palms and soles. Int J Dermatol 48(1): 73-75.

6. Soubeiran E, Wacker Jö, Hausser I, Hartschuh W (2008) Erythema elevatum diutinum with unusual clinical appearance. J Dtsch Dermatol Ges 6(4): 303-305

\section{ISSN: 2574-1241}

DOI: $10.26717 /$ BJSTR.2019.21.00362

Mohammed Al Abadie. Biomed J Sci \& Tech Res

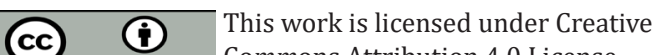

Submission Link: https://biomedres.us/submit-manuscript.php
7. Maruthappu T, Tharakaram S, Calonje E, Shirlaw PJ, Setterfield J (2012) Erythema elevatum diutinum with oral ulceration. Br J Dermatol 167(1): 222-224.

8. Rinard JR, Mahabir RC, Greene JF, Grothaus P (2010) Successful surgical treatment of advanced erythema elevatum diutinum. Can J Plast Surg 18(1): 28-30.

9. Rao GR, Joshi R, Phaneendra Prasad AK, Amareswar A, Sandhya S (2014) Nodular Erythema Elevatum Diutinum Mimicking Kaposi's Sarcoma in a Human Immunodeficiency Virus Infected Patient. Indian J Dermatol 59(6): 592-594.

$\begin{array}{ll}\text { BIOMEDICAL } & \text { Assets of Publishing with us } \\ \text { RESEARCHES } & \text { - Global archiving of articles } \\ \text { - Immediate, unrestricted online access } & \text { - Rigorous Peer Review Process } \\ & \text { - Authors Retain Copyrights } \\ & \end{array}$

